\title{
PENINGKATAN KUALITAS DAN PRODUKTIVITAS PANGAN TRADISIONAL ACEH IKAN KEUMAMAH BERSKALA INDUSTRI RUMAH TANGGA
}

\section{THE IMPROVEMENT OF QUALITY AND PRODUCTIVITY OF ACEHNESE FOOD “KEUMAMAH” IN HOME INDUSTRIAL SCALE}

\author{
V Muhardina1a dan TM Rahmiati² \\ ${ }^{1}$ Jurusan Teknologi Industri Pertanian, Fakultas Teknologi Pertanian, Universitas Serambi Mekkah, \\ Jalan Teungku Imum Lueng, Batoh, Banda Aceh, Indonesia \\ ${ }^{2}$ Jurusan Teknologi Pangan, Fakultas Teknologi Pertanian, Universitas Serambi Mekkah, \\ Jalan Teungku Imum Lueng, Batoh, Banda Aceh, Indonesia \\ a Korespondensi: Virna Muhardina, Email: virna.muhardina@serambimekkah.ac.id \\ (Diterima: 01-09-2017; Ditelaah: 01-09-2017; Disetujui: 26-10-2017)
}

\begin{abstract}
Keumamah is a typical Acehnese food product made from tuna that has been through the boiling, smoking and drying stage (known as keumamah fish or wooden fish). This product is processed manually by home industry, thus causing limitations in the quantity and quality production. This devotional activity aims to offer solutions by giving slicer and spinner tools to home industries "Keumamah Karya Nelayan" and "Keumamah Nelayan Pesisir" located in Lampulo, Banda Aceh, in order to increase their production capacity. This activity used method of introducing technology application from tools provided through discussion and practice. The results showed that the slicer produced $73.33 \%$ yield, 314 seconds of slicing time, and $23.35 \%$ slicing effectiveness. Spinner tool usage produced keumamah contained $4.15 \%$ oil content, with panelist acceptance level of taste, colour and texture was 4.00 (like).

Keywords: keumamah, home industry, spinner, slicer.
\end{abstract}

\begin{abstract}
ABSTRAK
Keumamah merupakan produk tradisional khas Aceh yang diolah dari ikan tuna yang telah melalui tahapan perebusan, pengasapan dan penjemuran (ikan keumamah atau ikan kayu). Produk ini diolah secara manual oleh industri rumah tangga, sehingga menyebabkan keterbatasan dalam kuantitas dan kualitas produksi keumamah siap saji yang dihasilkan. Kegiatan pengabdian ini bertujuan untuk memberikan bantuan alat pengolahan berupa slicer dan spinner kepada mitra usaha "Keumamah Karya Nelayan" dan "Keumamah Nelayan Pesisir" yang berada di Desa Lampulo Banda Aceh untuk memudahkan proses pengolahan dan meningkatkan kapasitas produksi. Pengabdian ini menggunakan metode introduksi teknologi dari alat yang diberikan melalui diskusi dan praktik. Hasil pengujian menunjukkan bahwa alat pengiris (slicer) menghasilkan rendemen 73.33\%, waktu pengirisan 314 detik, dan efektifitas pengirisan 23.35\%. Alat peniris minyak menghasilkan produk keumamah dengan kadar minyak 4.15\%, dengan tingkat penerimaan panelis adalah 4.00 (suka) terhadap rasa, warna dan tekstur keumamah.

Kata kunci: keumamah, industri rumah tangga, alat peniris minyak (spinner), alat pengiris ikan (slicer).

Iryani A, Sutanto, dan M Fathurrachman. 2017. Peningkatan kualitas dan produktivitas pangan tradisional Aceh ikan keumamah berskala industri rumah tangga. Qardhul Hasan: Media Pengabdian kepada Masyarakat 3(2): 140 - 145.
\end{abstract}




\section{PENDAHULUAN}

Provinsi Aceh adalah salah satu provinsi di Indonesia yang memiliki potensi perikanan yang cukup besar, dengan luas perairan laut $295.370 \mathrm{~km}^{2}$. Ketersediaan sumber bahan baku perikanan yang melimpah di Provinsi Aceh membuka peluang usaha yang cukup besar bagi masyarakat dalam meningkatkan pendapatan dan perbaikan di bidang ekonomi (LAKIP KKP, 2014). Salah satu komoditi perikanan yang banyak dijumpai di perairan Aceh adalah ikan tuna. Ikan ini menjadi bahan baku utama dalam pembuatan produk tradisional khas Aceh yaitu Keumamah. Ikan keumamah atau sering disebut sebagai ikan kayu adalah produk semi jadi yang telah melalui tahapan perebusan, pengasapan dan penjemuran, sehingga ikan ini memiliki umur simpan yang lebih lama dibandingkan ikan segar pada umumnya.

Ikan keumamah yang diproduksi oleh industri-industri rumah tangga di wilayah pesisir Aceh merupakan ikan keumamah mentah yang membutuhkan tahapan pengolahan lanjutan oleh konsumen. Hal ini menyebabkan nilai jual ikan keumamah masih sangat rendah. Di antara beberapa industri pengolahan ikan, terdapat dua mitra usaha yang mulai melakukan inovasi dalam mengolah ikan keumamah menjadi produk keumamah siap saji yang dapat langsung dikonsumsi oleh konsumen. Cara ini menjadikan nilai jual ikan keumamah menjadi lebih tinggi. Akan tetapi, kedua mitra masih memiliki beberapa kekurangan dan kelemahan dalam memproduksi keumamah yaitu proses pengolahan yang manual dan tradisional, sehingga kapasitas produksi, kualitas dan umur simpan produk yang dihasilkan masih rendah.

Proses pembuatan Keumamah terdiri dari tahap persiapan bahan baku dan pemasakan. Beberapa permasalahan yang ditemukan dari pengolahan keumamah pada kedua mitra antara lain persiapan bahan baku menggunakan metode konvensional, yaitu dengan pengirisan manual menggunakan pisau dapur biasa. Kelemahan metode ini adalah ikan hasil irisan memiliki bentuk dan ketebalan yang tidak seragam serta membutuhkan waktu yang lama, sehingga waktu produksi menjadi lebih panjang dan lama. Permasalahan lainnya adalah produk keumamah yang dihasilkan oleh mitra tidak dapat disimpan dalam waktu yang lama akibat kandungan minyak yang tinggi pada produk. Selama ini, produk keumamah yang dihasilkan mitra dikemas dan dijual dengan kondisi berminyak. Oleh karena itu, dibutuhkan suatu metode penirisan minyak yang tepat untuk mengurangi kadar minyak yang cukup tinggi pada produk keumamah.

Berdasarkan permasalah dan kendala yang dihadapi oleh mitra, kegiatan IbM ini menjadi penting untuk dilakukan dengan tujuan untuk memberikan solusi dan bantuan kepada mitra berupa alat pengolahan berteknologi yang dapat memudahkan proses pengolahan keumamah, meningkatkan efektifitas pengolahan, produktivitas, kualitas dan kuantitas produk yang dihasilkan oleh mitra. Produktivitas dan kualita yang baik dapat membantu peningkatan pendapatan mitra.

\section{MATERI DAN METODE}

Pelaksanaan kegiatan ini diselenggarakan di mitra usaha "Keumamah Karya Nelayan" di Desa Lampulo, Banda Aceh, yang juga dihadiri oleh mitra usaha "Keumamah Nelayan Pesisir". Pemilihan kelompok sasaran tersebut didasarkan atas pertimbangan kepentingan dan tujuan pengembangan teknologi pengolahan yang berkesinambungan dari usaha pengolahan ikan yang telah dijalankan oleh kedua mitra. Kegiatan ini dilaksanakan dengan menggunakan metode introduksi penggunaan teknologi dari alat yang diberikan kepada mitra. Metode ini dilakukan melalui diskusi dalam penyampaian materi. Pelaksanaan kegiatan juga dilengkapi dengan praktik langsung oleh mitra dalam pembuatan produk dan pengujian efektivitas alat yang diberikan. 


\section{HASIL DAN PEMBAHASAN}

Pengabdian dan pelatihan pembuatan produk serta pengujian alat pengolahan ini dilakukan di salah satu tempat produksi milik mitra yang dihadiri oleh anggota kelompok dari kedua mitra. Kegiatan ini difasilitasi oleh tim pengabdian Program Studi Teknologi Industri Pertanian dan Teknologi Pangan, Fakultas Teknologi Pertanian Universitas Serambi Mekkah Banda Aceh. Materi pelatihan dan pendampingan yang diberikan terkait dengan aplikasi teknologi pengolahan melalui penggunaan alat produksi yang diberikan oleh tim pengabdian, yaitu alat pengiris ikan keumamah (slicer) dan alat peniris minyak (spinner).

Penyampaian materi dilakukan melalui diskusi dan praktik pembuatan keumamah menggunakan slicer dan spinner. Kedua mitra menunjukkan antusiasme yang tinggi dalam mengikuti kegiatan ini karena mereka sangat menginginkan peningkatan kualitas dan kuantitas produk keumamah yang mereka hasilkan. Penggunaan kedua alat tersebut dapat membantu mitra dalam mencapai tingkat produktivitas dan mutu keumamah yang mereka inginkan.

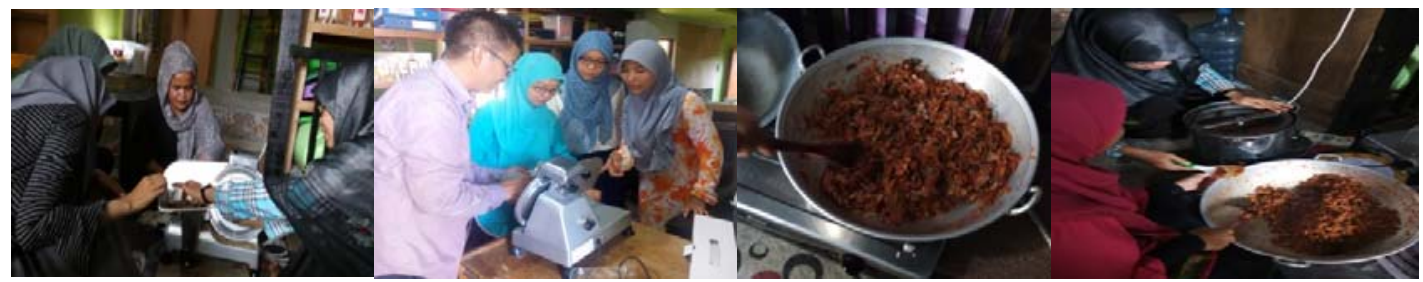

Gambar 1 Kegiatan pengabdian, pelatihan, dan pendampingan pengolahan Keumamah

\section{Rendemen dan Efektifitas Produksi}

Produksi keumamah yang dilakukan oleh kedua mitra selama ini berlangsung secara manual, yaitu dengan menggunakan peralatan tradisional. Kondisi produksi ini menyebabkan keterbatasan kuantitas produk bagi industri dalam memproduksi keumamah. Proses persiapan bahan baku yaitu pengirisan ikan merupakan salah satu tahapan proses pengolahan yang membutuhkan waktu yang lama. Lamanya waktu pengirisan ini disebabkan oleh pengirisan ikan menggunakan pisau dapur. Hal ini mempengaruhi lamanya waktu pengolahan keumamah secara keseluruhan, sehingga membatasi jumlah produk yang

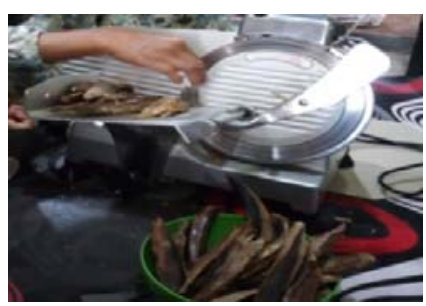

(a) dihasilkan. Oleh karena itu, dibutuhkan alat otomatis yang dapat mengiris ikan keumamah, sehingga waktu persiapan bahan baku menjadi lebih cepat, waktu pengolahan keumamah secara keseluruhan menjadi lebih singkat, dan kuantitas ikan keumamah yang diolah per harinya menjadi lebih banyak.

Pada kegiatan ini, tim pengabdi memberikan alat pengiris ikan (slicer) (Gambar 2a) yang bertujuan untuk mempermudah proses persiapan bahan baku, mempersingkat waktu produksi dan meningkatkan jumlah produk yang dihasilkan, serta meningkatkan keseragaman ukuran irisan ikan yang dihasilkan.

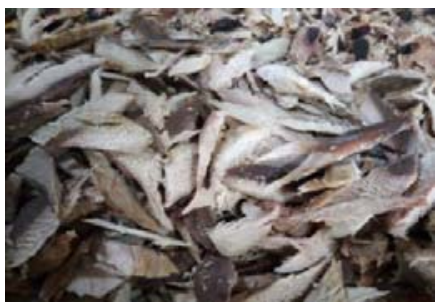

(b)

Gambar 2 (a) Pengirisan ikan menggunakan slicer; (b) Hasil irisan ikan

Pengujian slicer dilakukan dengan mengiris langsung sejumlah ikan keumamah yang akan digunakan untuk produksi keumamah siap saji. Pada pengujian ini 
dilakukan penghitungan total bagian ikan hasil pengirisan dan bagian terbuang yang ditunjukkan oleh nilai rendemen, total waktu pengirisan ikan, dan efektifitas pengirisan yang dihitung berdasarkan perbandingan rendemen terhadap waktu pengirisan. Rendemen, waktu pengirisan dan efektifitas pengirisan dapat dilihat pada Tabel 1.

Tabel 1 Perbandingan efektifitas pengolahan antara pengirisan manual dengan slicer

\begin{tabular}{lrr}
\hline \multirow{2}{*}{ Parameter } & \multicolumn{2}{c}{$\begin{array}{c}\text { Metode Pengirisan Ikan } \\
\text { Keumamah }\end{array}$} \\
\cline { 2 - 3 } & \multicolumn{1}{c}{ Manual } & \multicolumn{1}{c}{ Slicer } \\
\hline Rendemen & $96,67 \%$ & $73,33 \%$ \\
Waktu & 728 detik & 314 detik \\
Pengirisan & & \\
Efektifitas & $13,28 \%$ & $23,35 \%$ \\
Pengirisan & & \\
\hline
\end{tabular}

Berdasarkan Tabel 1 dapat dilihat bahwa rendemen yang dihasilkan dari pengirisan manual lebih tinggi dibandingkan pengirisan menggunakan slicer. Hal ini dikarenakan sebagian kecil ikan keumamah yang diiris menggunakan slicer terpotong sangat halus dan keluar pada bagian bawah mata pisau yang berputar. Bagian ikan ini tidak digunakan dan dianggap sebagai bagian yang terbuang, yaitu sekitar $26.67 \%$. Akan tetapi, waktu pengirisan dengan menggunakan slicer sangat singkat dibandingkan pengirisan secara manual, sehingga dapat diketahui bahwa pengirisan menggunakan slicer lebih efektif hampir dua kali lipat (23\%) dibandingkan secara manual (13\%).

\section{Kadar Minyak Keumamah}

Keumamah merupakan produk tradisional olahan ikan yang menggunakan sejumlah minyak untuk proses pengolahannya. Tingginya kandungan minyak pada produk akhir keumamah menjadi salah satu faktor penyebab rendahnya umur simpan pada produk ini. Lemak yang berinteraksi dengan udara (oksigen) menyebabkan terbentuknya peroksida yang bersifat tidak stabil dan mudah mengalami penguraian menjadi senyawa-senyawa turunan seperti aldehid, keton dan senyawa lainnya dengan berat molekul rendah (Gulcin, 2012).

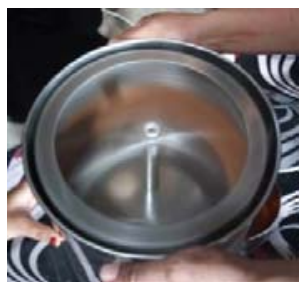

(a)

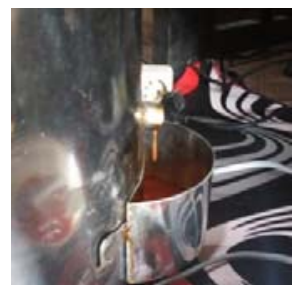

(b)

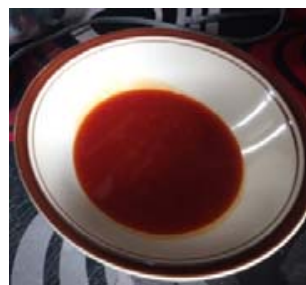

(c)

Gambar 3 (a) penirisan keumamah menggunakan spinner; (b) pemisahan minyak dari produk; (c) minyak yang telah ditiriskan

Senyawa-senyawa ini menyebabkan ketengikan pada produk yang berminyak dan berlemak. Ketengikan pada produk keumamah menyebabkan produk mengalami penurunan kualitas dan daya jual. Cara yang tepat untuk memperpanjang masa simpan keumamah dan menghambat reaksi oksidasi dan ketengikan pada produk adalah dengan menghilangkan sebagian minyak yang ada pada keumamah. Cara ini dapat dilakukan dengan meniriskan minyak menggunakan alat spinner. Penirisan menggunakan spinner seperti ditunjukkan oleh Gambar 3.
Tabel 2 Kadar minyak keumamah tanpa dan dengan penirisan (spinner)

\begin{tabular}{lcc}
\hline \multirow{2}{*}{ Parameter } & \multicolumn{2}{c}{ Keumamah } \\
\cline { 2 - 3 } & $\begin{array}{c}\text { Tanpa } \\
\text { Penirisan }\end{array}$ & $\begin{array}{c}\text { Dengan } \\
\text { Penirisan } \\
\text { (Spinner) }\end{array}$ \\
\hline $\begin{array}{l}\text { Kadar } \\
\text { Minyak }\end{array}$ & $21,07 \%$ & $4,15 \%$ \\
\hline
\end{tabular}

Spinner ini menerapkan sistem sentifugal dimana kecepatan putar pada wadah peniris menyebabkan minyak yang memiliki massa jenis lebih rendah dari produk terpisah dan 
keluar dari bahan. Kadar minyak pada keumamah dapat dilihat pada Tabel 2 .

Dari Tabel 2 dapat dilihat perbedaan kadar minyak yang signifikan antara keumamah tanpa penirisan dan dengan penirisian menggunakan spinner. Kadar minyak pada produk yang ditiriskan sebesar seperlima dari kadar minyak pada keumamah tanpa penirisan. Hal ini menunjukkan bahwa produk keumamah yang telah ditiriskan dari minyak diduga memiliki umur simpan dan daya awet lebih tinggi dibandingkan keumamah tanpa penirisan. Selain itu, rendahnya kadar minyak pada keumamah yang telah ditiriskan dapat memberikan jaminan kesehatan yang lebih baik kepada konsumen.

\section{Pengujian Organoleptik}

Produk keumamah tanpa penirisan dan dengan penirisan menggunakan spinner, kemudian diujikan pada panelis untuk melihat tingkat penerimaan dan kesukaan terhadap produk yang dihasilkan. Produk keumamah dan hasil pengujian organoleptik dapat dilihat pada Gambar 4 dan Tabel 3.
Tabel 3 Tingkat kesukaan panelis terhadap organoleptik Keumamah

\begin{tabular}{lrr}
\hline $\begin{array}{c}\text { Atribut } \\
\text { Mutu }\end{array}$ & $\begin{array}{c}\text { Tanpa } \\
\text { Penirisan }\end{array}$ & $\begin{array}{c}\text { Dengan } \\
\text { Penirisan } \\
\text { (Spinner) }\end{array}$ \\
\hline Rasa & 4.63 & 3.88 \\
Warna & 4.60 & 4.20 \\
Tekstur & 4.20 & 4.00 \\
\hline
\end{tabular}

Berdasarkan Tabel 3 dapat dilihat bahwa, secara keseluruhan, rata-rata tingkat kesukaan panelis terhadap kedua produk adalah 4 - 5 yaitu suka hingga sangat suka. Terdapat sedikit perbedaan tingkat kesukaan antara kedua produk yang diujikan. Keumamah tanpa penirisan lebih disukai dari ketiga atribut mutu yang diujikan yaitu rasa, warna dan tekstur dibandingkan keumamah dengan penirisian. Hal ini sangat dimungkinkan karena sebagian senyawa pembentuk rasa dan aroma pada bumbu keumamah ikut terpisahkan dari produk pada saat penirisan. Permasalahan ini dapat ditangani dengan melakukan pemasakan keumamah pada waktu yang lebih lama, sekitar 7 hingga 8 jam menggunakan api kecil dibandingkan lama waktu pemasakan yang dilakukan pada pelatihan ini, yang hanya sekitar 2 jam.

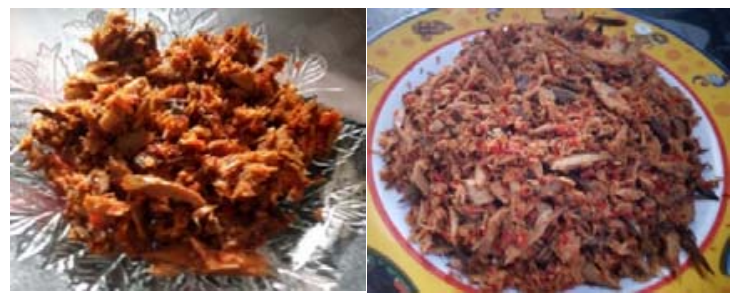

(a) (b)

Gambar 4 (a) Keumamah tanpa penirisan; (b) Keumamah setelah ditiriskan menggunakan spinner

\section{KESIMPULAN DAN IMPLIKASI}

Dari kegiatan pelatihan dan pendampingan ini dapat disimpulkan bahwa alat pengolahan slicer dan spinner yang diberikan dapat meningkatkan efisiensi produktivitas berupa efektifitas pengirisan sebesar $23.35 \%$, dan menurunkan kandungan minyak hingga menjadi $4.15 \%$ setelah penirisan. Kedua alat yang diberikan menunjukkan adanya peningkatan produktivitas dan kualitas produk keumamah yang dihasilkan oleh mitra. Sebaiknya kondisi dan lama pemasakan keumamah dilakukan lebih lama dan disesuaikan dengan tekstur ikan keumamah yang digunakan, untuk menjamin bumbu yang digunakan dapat meresap dan menciptakan rasa dan aroma yang khas pada produk, meskipun telah dilakukan penirisan minyak. 


\section{UCAPAN TERIMA KASIH}

Ucapan terima kasih disampaikan kepada Kemenristek Dikti melalui Kopertis wilayah XIII atas dana pengabdian, LPPM Universitas Serambi Mekkah dan segenap staf akademik Fakultas Teknologi Pertanian Universitas Serambi Mekkah yang telah membantu dalam pelaksanaan pengabdian ini.

\section{DAFTAR PUSTAKA}

[LAKIP KKP] Laporan Akuntabilitas Kinerja Kementrian Kelautan dan Perikanan. 2014. Kementrian Kelautan dan Perikanan, Jakarta.

Gulcin, I. 2012. Antioxidant activity of food constituents: an overview. Arch Toxicol (2012) 86:345-391. 